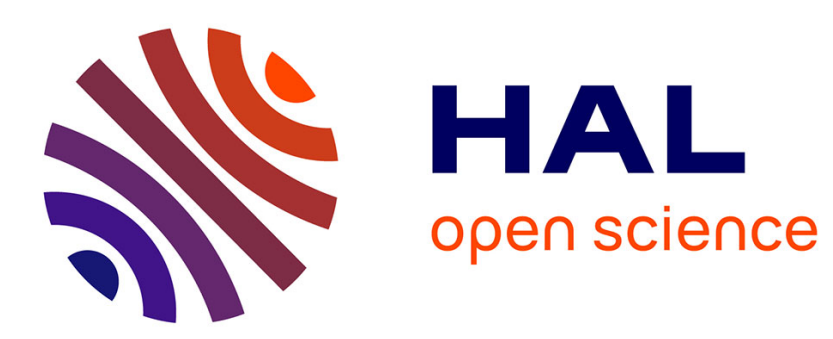

\title{
Acclamation Voting in Sparta: An Early Use of Approval Voting \\ Charles Girard
}

\section{To cite this version:}

Charles Girard. Acclamation Voting in Sparta: An Early Use of Approval Voting. J.-F. Laslier et R. Sanver (dir.), Handbook on approval voting, Heidelberg, Springer, 2010, p. 15-18., 2010. hal03005701

\section{HAL Id: hal-03005701 \\ https://hal.science/hal-03005701}

Submitted on 14 Nov 2020

HAL is a multi-disciplinary open access archive for the deposit and dissemination of scientific research documents, whether they are published or not. The documents may come from teaching and research institutions in France or abroad, or from public or private research centers.
L'archive ouverte pluridisciplinaire HAL, est destinée au dépôt et à la diffusion de documents scientifiques de niveau recherche, publiés ou non, émanant des établissements d'enseignement et de recherche français ou étrangers, des laboratoires publics ou privés. 


\title{
Acclamation Voting in Sparta: \\ An Early Use of Approval Voting
}

\author{
Charles Girard, Université François Rabelais de Tours
}

(Version auteur)

in J.-F. Laslier et R. Sanver (dir.), Handbook on approval voting, Heidelberg, Springer, 2010, p. 15-18.

An early form of approval voting was arguably used in Ancient Greece, as is described in Plutarch's account of the elections to the Gerousia, Sparta's Council of Elders.

In his Life of Illustrious Men, Plutarch credits the legendary lawgiver Lycurgus with having fixed the rules for electing the Spartan Council's members, the Gerontes. The office of Elder was seen as a reward for virtue and as a high honor, since the Gerontes were elected for life and the Gerousia was a powerful institution - it pre- pared legislation for approval by the Assembly and acted as a high court in serious cases such as those of homicide (Staveley 1972 p. 76). Plutarch recounts that, after having filled the Council with men chosen among his followers, Lycurgus ordered that the future vacancies "be supplied out of the best and most deserving men past sixty years old”:

We need not wonder if there was much striving for it; for what more glorious competition could there be amongst men, than one in which it was not contested who was swiftest among the swift or strongest of the strong, but who of many wise and good was wisest and best, and fittest to be entrusted for ever after, as the reward of his merits, with the supreme authority of the commonwealth, and with power over the lives, franchises, and highest interests of all his countrymen? (Plutarch 1876 p. 40)

Although it is likely that only aristocrats were entitled to put themselves forward as candidates, the rules organizing the selection of the 28 Gerontes were designed to favor merit, 
and not only birth or wealth. And while elections to the Gerousia involved some form of lottery, it was not exactly an election by lot, as was often the case in Greek democracies. Sparta resorted to a very specific form of election, in which voting was conducted by shouting:

The manner of their election was as follows: The people being called together, some selected persons were locked up in a room near the place of election, so contrived that they could neither see nor be seen, but could only hear the noise of the assembly without; for they decided this, as most other affairs of moment, by the shouts of the people. This done, the competitors were not brought in and presented all together, but one after another by lot, and passed in order through the assembly without speaking a word. Those who were locked up had writing-tables with them, in which they recorded and marked each shout by its loudness, without knowing in favour of which candidate each of them was made, but merely that they came first, second, third, and so forth. He who was found to have the most and loudest acclamations was declared senator duly elected. (Plutarch 1876 p. 40)

Elections to the Gerousia thus involved "an early form of applaudometer" (Elster 1989 p. 85), in which whoever was judged to have received the loudest acclaim was elected. Aristotle notoriously denounced this procedure as “childish” (Aristotle 1984), probably because he considered it a blatantly inappropriate way to select the most competent among the citizens he was also critical of the fact that individuals had to put themselves forward as candidates to the Gerousia, a rule more suitable for ambitious men than for virtuous ones.

Aristotle is not alone in judging the Spartan Shout harshly. Historians have deemed the procedure "primitive” (Staveley 1972 p. 74), interpreting it as a sign that Spartans had "no notion of 'one man one vote"' (Cartledge 2001 p. 51). Con- temporary political theorists even invoke the "Spartan Shout" as a negative model, contrasting it with the positive example of Athenian democracy. In Fishkin’s view “missing in the Spartan method was the entire social context of careful debate and deliberative argument fostered by the Athenian institutions:: :. Yet if we ask which model of ancient democracy we have come closer to realizing in our modern quest for direct democracy, we must concede that there are ways in which the Spartan model is closer than the Athenian to contemporary practices” (Fishkin 1997 p. 24). Elections to the Gerousia are even seen as the precursors of today's media “applau- dometers,” in which citizens influence politicians in proportion to their loudness. "The sting of an offensive sound 
bite arouses a populace that is only sound-bitten. The ire of talk-show democracy has given us a mass electronic version of the Shout” (Fishkin 1997 p. 25).

Critics of the Shout thus question the ability of the Spartan Assembly to select the wisest and the best among the candidates on at least two counts: Because it required citizens to shout as the candidates were presented in random order, it precluded careful consideration and deliberation; and because it was based on the auditory evaluation of a collective shout, it did not give an equal voice to each citizen but favored the loudest and the most motivated among the Assembly's members.

However, far from being inexplicably primitive, the Spartan way of proceed- ing seems to have been designed to respond to specific concerns regarding the impartiality of the election. The use of the lottery to decide the candidates’ order of appearance was most likely meant to ensure the spontaneity of the procedure. "The order in which the candidates appeared was the key to the whole proceed- ings. Despite the opportunities which an allotment behind closed doors might have presented for collusion, it is most unlikely that lots were drawn in the presence of the Assembly itself, if only because foreknowledge of the order in which the candidates would present themselves would inevitably have detracted from the ele- ment of spontaneity in the shouting which was so necessary to the credibility of the vote” (Staveley 1972 p. 74). Such precautions may not have been enough to prevent strategies of manipulation, especially by Sparta's kings and their families (Birgalias 2007 p. 347), but spontaneity was not the Shout's only upside.

Although Plutarch's succinct account does not allow us to draw very precise conclusions, it is clear that the Assembly's members were free to acclaim several candidates. To this extent, the shout appears as an early form of approval voting, in which each elector either approves or disapproves each candidate, the winner being the one that is approved by the greatest number of electors. In the absence of ballots, the Spartan version of approval voting appears clearly imperfect: individual voices may differ in loudness, and one can imagine the Assembly's members adjusting the intensity of their cheering to the intensity of their support for each of them. Further- more, it involved a very approximate method of aggregation: clumping voices rather than counting ballots. Nonetheless, the Shout roughly satisfies the formal requisites of approval voting: it was a multi-candidate contest consisting in a single round of voting that allowed each participant to support as many candidates as desired, leading to an - admittedly crude - summation of the support received by each candidate. Looking to fill the Gerousia with men recognized by all as virtuous, Sparta's law- givers might have been aware of the advantages offered by such a form of election, which favors the candidate 
with the greatest overall support.

If we are to trust Plutarch's account of the way they celebrated the winner, the Spartans themselves apparently believed that acclamation voting was a satisfying form of election. "Upon [his election] he had a garland set upon his head, and went in procession to all the temples to give thanks to the gods; a great number of young men followed him with applauses, and women, also, singing verses in his honour, and extolling the virtue and happiness of his life” (Plutarch 1876 p. 40).

\section{References}

Aristotle (1984). Politics. In J. Barnes (Ed.), B. Jowett (Trans.), The complete works of Aristotle.

Princeton: Princeton University Press.

Birgalias, N. (2007). La Gérousia et les gérontes de Sparte. Ktema, 32, 341-349.

Cartledge, P. (2001). Spartan reflections. Berkeley: University of California Press.

Elster, J. (1989). Solomonic judgements: Studies in the limitations of rationality. Cambridge: Cambridge University Press.

Fishkin, J. (1997). The voice of the people: Public opinion and democracy. New Haven: Yale University Press.

Plutarch (1876). Lycurgus. In A. H. Clough (Ed.), J. Dryden (Trans.), Lives of illustrious men.

London: Sampson Law, Marston, Searle, \& Rivington.

Staveley, E. S. (1972). Greek and Roman voting and elections. London: Thames and Hudson. 